\title{
Locally Advanced Gastrointestinal Stromal Tumor
}

National Cancer Institute

\section{Source}

National Cancer Institute. Locally Advanced Gastrointestinal Stromal Tumor. NCI

Thesaurus. Code C150739.

Gastrointestinal stromal tumor that has spread from its original site of growth to nearby tissues or lymph nodes. 